Јелена Јовановић Симић

Универзитет у Београду

Филолошки факултет
УДК 070:316.774

дОИ https://doi.org/10.18485/

melissa.2016.15.1.ch3

\title{
НЕКА ЗАПАЖАЊА О КАРАКТЕРИСТИКАМА СРПСКОГ ИНТЕРНЕТ НОВИНАРСТВА
}

\section{Сажетак}

Аутор утврђује ${ }^{1}$ одређене предности интернет новинарства, и примећује да су оне пре свега садржане у чињеници да се сваког тренутка појављују нове опције, нове могућности које од овакве врсте новинарства чине чврст основ напретка који ће једног дана, сигурно, довести до тога да штампано издаваштво, и новинарство које је ограничено само на штампане медије, буде потиснуто, а можда и потпуно заборављено. На крају анализе интернет издања једног од најтиражнијег српског листа - Блица, аутор скреће пажњу и на извесне опасности по друштво, по опште стање и духовну атмосферу друштва - које носи ова иновативност у комуникацијском процесу.

Кључне речи: медиологија, комуникологија, штампа, интернет, издаваштво, електронско издање.

\section{1. Уводне напомене}

1. Опште је познато да су новине, радио, телевизија и интернет огледало друштва: промене стања у друштву доприносе променама у писању, као што се и промене у писању рефлектују, пре свега, на културно стање у друштву.

a) О немогућности да се појам снаге или немоћи јавне речи ${ }^{2}$ апсолутизује говори се и у извештају Међународне комисије UNESCO-а за изучавање проблема комуникације, чија је суштина садржана у наслову Много гласова један свет! У њему се, поред осталог, каже (ИМК 1980: 11):

1 Овај рад је написан у оквиру пројекта 178006 Српски језик и његови ресурси, који финансира Министарство за науку и развој Републике Србије. 
Способност комуникације да активира, социјализује, хомогенизује, па чак и адаптира људе њиховој сопственој култури, увек је била прецењивана... Други посматрачи били су, пак, уверени да средства комуникације имају тако снажан друштвени утицај да могу своју публику да натерају да мисли и да се понаша на одређен начин. Нема сумње да средства масовне комуникације - штампа, радио и телевизија [и интернет] - заиста имају способност не само да одражавају, већ и да формирају мишљење, и да одиграју улогу у формирању ставова. Међутим, многи посматрачи мисле да ова средства производе нестварну слику реалног света, уместо да му нуде шири спектар знања и избор у поимању ствари...

Треба се упитати јасно и гласно: Како комуникација, а посебно масовна, функционише као агенс друштвене промене, и које су њене границе? Изгледа претерано проглашавати медије за творце свих повољних промена, или за чуваре свега што треба неговати; с друге стране, изгледа такође претерано прихватити повике оних који оптужују медије као узрочнике опадања квалитета живљења, губљења локалних традиција и свођења културе на елементарни ниво. Упркос знатном утицају комуникације, погрешно би било приписати јој више врлина, више грешака, или већу силу него што је стварно има.

б) Уместо бледог трчкарања за догађајима, медији ${ }^{3}$ су доживели корениту, позитивну метаморфозу. Проширени су простори обавештавања, отворене раније добро забрављене капије информација, разбијен тамни вилајет доскорашњих табу тема. Има, међутим, у томе хуку набујале јавности - поступака и акција појединих медија који наносе штету новинској професији и јавној речи у целини. У трци за тиражом и престижом објављују се непроверене информације, денуцира, не бирају се речи у обрачуну на јавној сцени.

2. Експанзија медијских технологија, на то истраживачи скрећу пажњу - изазвала је интернет револуцију, а све заједно до-

3 О поменутим и сличном питањима у вези са медијима као огледалом друштва детаљније говори Тадић (2002: 13). 
принело је значајним променама у квантитету и квалитету преноса информације. Процес увећања интерконекција довео је до нових процеса глобализације ${ }^{4}$, па и нових појава као што је интернет ${ }^{5}$ глобализација.

а) Свакако да су се овакве културолошке и комуниколошке промене одразиле и на лингвистички и стилски статус језика. Екстралингвистички моменти више него у претходном периоду развоја српског језика - модификују традиционалне језичке токове. То је разумљиво ако се узме у обзир да се српски језик нашао у новом друштвеном интернализованом контексту. Под принудом комуникацијске динамике - језичке форме свих структурних нивоа у интернет комуникацији доживљавају преоблику - најчешће у виду различитих редукција, али и економисања друге врсте супстандардне категоризације.

б) Питањем 'онлајн' језика посебно се бавио Дејвид Кристал (2001) - утврђујући да се овакав језик не може сматрати ни 'говорним писањем' ни 'написаним говором' ${ }^{6}$, већ да је реч о некој прелазној форми која има особине и једног и другог. Та прелазна комуникативна форма представља засебну врсту интеракције међу људима посредством компјутерске технике - коју Кристал назива нет-говором (netspeak). Такав облик говора по себи представља једну лингвистичку необичност ${ }^{7}$ он не само да је иновативан, већ је и разноврстан. У овом смислу занимљиво је пратити неологизме (sajber spejs,

4 „Глобализација се може дефинисати као интензификација друштвених односа на светском плану, која повезује удаљена места на такав начин да локална збивања уобличавају догађаји који су се одиграли километрима далеко и vice versa" (Gidens 1998: 69)

5 Милановић (2003) говори о интернет глобализацији као узајамној зависности која постоји између развоја интернета, као носиоца глобалног утицаја информационо-комуникационих технологија, и друштвених структура на којима интернет почива и које саме све више почивају на њему.

$6 \quad$ „It is neither spoken wririting, nor written speach“ (Crystal 2001: 238).

7 Као основне карактеристике нет-говора, Кристал истиче следеће (2001: 42): „временска ограниченост // просторна ограниченост, спонтаност (у реалности) // фиктивност (одсуство реалног контекста), комуникација лицем у лице // одсуство визуелног и аудитивног ефекта, некохезиона структура // јака кохезиона структура, друштвена интерактивност (неформалност) // фактографија (научност), обострана визуелна перцепција // могућност поновљеног читања, прозодијско богатство // графичко богатство“. 
е-пословање и сл.), те и сам стил писања, нове знаке интерпункције, и посебно нове врсте графичких знакова.

3. Данас у Србији има много медија, али са друге стране мали број новинара који би требало да их пуне садржајем у виду информација. Мали, готово ограничен број електронских издања новина и часописа годинама је већ скоро непромењен. Тек по који часопис донесе свежину у онлајн издаваштво ${ }^{8}$, али она је кратког века и пролазна као и сам часопис (2002: 235). Једине праве информативне интернет странице које се редовно одржавају јесу сајтови Б92 и РТС-а (Станојевић 2010).

а) Интернет издања новина и часописа код нас представљају само електронски облик штампаног издања, без икаквих промена и пролагођавања (исп.: Новосел и др. 2006). По правилу, у нашем интернет издаваштву, нема додатног прилагођавања текста, текст се поставља на интернету онакав какав је у објављен у дневним листовима, чак се у великом броју случајева ни хиперлинкови ${ }^{10}$ не обележавају, тако да је текст електронских издања у великом броју случајева идентичан тексту штампаног издања. Интернет издања, међутим, пружају могућност да текст буде дужи, што и јесте пракса у великим компанијама онлајн издаваштва у иностранству. У Србији то није случај, док у иностранству репортери и новинари пишу две верзије текста - дужу и краћу, за онлајн и за штампано издање, у Србији се исти текст пренесе на интернет и ту остави, без икакве дораде или проширења.

б) Упркос овој чињеници, позната је сколоност српских новинара ка колумни као омиљеном облику интернет изражавања, па зато и не чуди велика популарност блогова међу новинарима. У овом тренутку у стању српског новинарства, блогови су једини облик онлајн новинарства који има шансу да траје у нашој земљи.

\footnotetext{
У нашој земљи присутне су и презентације страних медија. Доступно на: http://www.blogodak.com/?search=naravno\&page=380 [21. март, 2010]. Хиперлинк - успоставља хипертекстуалну структуру документа записаног у посебном формату, тако што омогућава да се повеже неки фрагмент текућег текста са неким другим делом тог, или пак неког другог текста (Вујаклија 1991: 983).
} 


\section{2. Анализа електронског издања дневног листа Блиц ${ }^{11}$}

1. Дневни лист Блиц представља најтиражнији дневни лист данас у Србији. Његовом великом тиражу доприноси и добро организована интернет страница, која не представља само другу форму штампаног издања, већ (не потпуно, али) у великој мери промењено и прилагођено штампано издање.

а) Наиме, већ са самом насловном страном читалац је уведен у свет електронског издаваштва. Густа, шаролика мрежа визуелних утисака оставља снажан утисак већ при самом отварању оваквог издања. Временска прогноза, курсна листа и дневни хороскоп прате сваку активност омогућавајући тако стални приступ тим информацијама.

б) Амбијент насловне стране и читавог листа у електронском издању учињен је необичнм због нових призора који се стално смењују пред очима посматрача и тако на њега делују као носиоци виших вредности.

2. Веома је карактеристичан и начин конституисања архиве. Наиме, архива није организована на класичан, календарски начин, по коме се одабиром датума добија издање листа тог дана, већ на нови, веома практичан начин који почива на асоцијативним сноповима. Доминантна реч, лајтмотив текста који се чита, изазива сноп асоцијација у више смерова, од којих сваки води ка неком новом тексту. Такав начин организације подсећа на хипертекст, али он то још увек није. Док се у хипертексту смернице, односно асоцијативне речи у облику линкова налазе у самом тексту, дотле су у текстовима овог дневног листа оне распоређене ван основног текстуалног дела, али са јасним и добро маркираним назнакама. Оваква структура је добро организована формација у којој компоненте једна другу подржавају и у савршеном су складу, па једна без друге не могу да постоје. Тако, уколико читамо неки чланак на пример о неком спортском догађају, поред тог чланка ће се отворити још многи, из неких ранијих бројева, чија се основна нит подудара са основним смерницама чланка који смо одабрали.

а) Без икакве селекције рубрика из штампаног издања, онлајн издање нуди и нове могућности. Наиме, у онлајн верзији овог листа

11 Доступно на: http://www.blic.rs 
омогућено је истовремено прелиставање свих додатака који током недеље излазе, без обзира на дан њиховог излажења. Блиц Плус, додатак Жена, са својим посебном додатком под називом Љубавни роман, постављени су у свим бројевима одмах на саму почетну страну, што у великој мери олакшава сналажење.

б) Такође, електронско издање дневних новина Блиц у великој мери користи могућности које сам интернет пружа. Наиме, тренутно актуелне, најновије вести (којих још увек нема у штампаном издању) прате апсолутно сваку страницу која се отвори. Поред њих сваку страницу прате и вести које су најчитаније, као и оне које имају највише коментара читалаца. Такође, опција галерија омогућава бржи преглед слика како из последњег, тако и из ранијих бројева. Поред тога, у оквиру опције видео́ могу се погледати снимци који се односе на штампане текстове и који тако појачавају и утврђују утиске, доприносећи да се створи потпуна слика догађаја на који се односи новински чланак.

3. Већ је раније назначено да је колумна омиљени облик интернт извештавања код нас, па зато је и посебан простор који је Blic online одвојио за писање блогова - једно од најпосећенијих места на интернету. Детаљан попис свих људи који објављују блогове, добра организација простора - јер су текстови разврстани по темама, - доприносе томе да је интересовање за овај вид новинарства веома високо.

а) Такође, уз сваки текст објављен на сајту ових новина постоји посебно место за коментаре читалаца, који са великом прецизношћу осликавају начин на који информација, пренесена овим медијем, допире до реципијената. Тако посматрајући кометаре читалаца може се стећи утисак о томе на који начин типологија одабира теме утиче на читалачку публику; - што се лепо перципира из следећег примера ${ }^{12}$ :

„Ovo je lepa priča o Vasi Ladačkom

Aleksandra Držaić | 13. 04. 2010. - 00:02h | Komentara: 232

Rediteljski prvenac Đorđa Balaševića premijerno će biti prikazan 19. aprila u Novom Sadu i 20. u „Sava centru“ u Beogradu.

12 Извор: http://www.blic.rs/Zabava/Vesti/184763/Ovo-je-lepa-prica-o-Vasi-Ladackom/ komentari\#ostali, 14. април 2010. 
Film „Kao rani mraz" dugo se krčkao u porodičnoj producentskoj kući „Salazka“ i sada je spreman za prikazivanje. Reditelj, koji je napisao i scenario i muziku, na kraju je složio priču o najslavnijem Vasi u Vojvodini u dva i po sata filma.

Film „Kao rani mraz" neće izneveriti sve one koji vole baladu o Vasi Ladačkom, tvrdi Balašević.

Čuli smo da priča o Vasi Ladačkom neće biti tužna... Kakav nas film očekuje?

- Hej? Podsećam vas da pričate s likom koji je napisao „Sve prave su ljubavi tužne...", a Vasina ljubav je prava, to smo se valjda dogovorili? No, dobro, bili smo u stvari isprovocirani da se upustimo u ovu avanturu, pojavile su se lopine koje ne kradu više samo stihove i ideje iz pesama, nego su počeli da marišu i glavne junake, pa smo to želeli da predupredimo. Ukratko, oni koji vole tu baladu, neće biti iznevereni, a onima koji je ne vole, stvarno ne mogu pomoći...

Poslednje dve godine imali smo priliku da gledamo dve serije o Vojvodini - "Jesen stiže" $i$ "Sva ta ravnica". Da li ste ih gledali i šta o njima mislite?

- Iz prvopomenute serije video sam nekoliko kadrova, tek koliko mi se zaglavilo dugme na daljinskom, ali možda i grešim jer to što sam usput video i nije imalo veze sa Vojvodinom? Za drugu seriju sam čuo, ali bojim se da je emitovana diskretnije nego što je najavljivana, tako da, nažalost, nisam uspeo i da je vidim. Jednom prilikom ste rekli da u ovoj priči ima i pomalo jugonostalgije jer Vasu Ladačkog znaju i u Mostaru, Ljubljani, Splitu...

Da li ste zbog toga imali odličnu ekipu glumaca koji potiču iz bivše Jugoslavije?

- Vasa se odavno oteo i nastavio da živi nekim svojim životom, krišom je stizao tamo gde niko odavde jedno vreme nije smeo, tvrdoglavo ostajao u gradovima iz kojih su svi drugi pobegli. Dugo već nemam starateljstvo nad njim. Smatraju ga svojim gde god ga razumeju bez titla, nailazim na njegove tragove čak i na kontinentima na koje kročim prvi put, citiraju mi ga šapatom iz mraka, njegovim rečima kite narodnjačke refrene. Šerbedžija, Mustafa, Mira Banjac, Meto Jovanovski, svi ovi divni klinci i mi, samo smo zajednički prija- 
telji tog probisveta. I svaka čast bivšoj Jugoslaviji, ali da je vredela, ne bi bila bivša. I u navedenom društvu osećam se suviše moćno da bi(h) se merio prema njoj...

U filmu ćemo čuti Georgija Zamfira na pan-fruli, koji je odsvirao naslovnu numeru za film "Bilo jednom u Americi" i Martu Šebešćen(,) koja je poznata po numeri iz filma "Engleski pacijent". Kako je došlo do saradnje s njima?

- Polaskan sam pristojnošću kojom su Marta i maestro Zamfir izvezli svoja imena na skromnom rubu tog šarenog svatovskog peškira, na ono malo preostalog mesta koje smo im ponudili. Nažalost, nisam mogao ni slutiti da će Moj Producent na zahtev da mi nađe nekog s glasom Marte Šebešćen dovesti upravo Martu Šebešćen, a za "tonove koje bi mogao odsvirati jedino Zamfir“, onda obezbediti Zamfira lično? Sasvim je sigurno da oni zaslužuju daleko više prostora, ali sad je i potpuno sigurno da oni znaju tajnu kojom se i najmanji prostor čarolijom pretvara u veliki. A Olivera je jednostavno iz iste bajke s njima i samo zato su se tako lako ukrcali na leteći ćilim njenog entuzijazma. Uzgred, ja tu ni ne falim puno. Sve negde do špice...

Glumci su u šali rekli da će Vas na premijeri predstaviti kao reditelja koji se na početku karijere bavio muzikom. Kako vam je izgledao rediteljski posao?

- Tridesetak godina sam na sceni, pa ipak još nikad nisam sebe nazvao muzičarem, tako da me ni to što sam radio na jednom filmu neće zablesaviti da se sad proglašavam rediteljem. Među nama budi rečeno, rediteljski posao mi uopšte nije izgledao kao posao, a moja strogost je poslovično prikrivena, kao mina sa odloženim dejstvom, mislim da je na neke tek ovih dana dejstvovala.

Ko je do sada pogledao film i kakvi su komentari?

- Poneki saradnik, poneki prijatelj, ne puno njih. I komentari su suviše pozitivni da bih se usudio da ih smatram objektivnim, pa samim tim i navedem...

Mika

Sreda, 14. 04. 2010. 00:01h

Ma mnoooooooooooooogo je,kume mnogo je!!!! A ovo je kao njegov Novi Sad, njegov grad... Ja ga zaista volim, postujem i 
obozavam njegove pesme i jedva sam cekala da se film pojavi, ali sada kada vidim koliko je karta, jako sam se razocarala :///

\section{grbavica021}

Utorak, 13. 04. 2010. 17:54h

Sta se cudite? Da ste bili na njegovim koncertima, da ste slusali viceve i sale izmedju pesama.....razumeli bi ste sta on ovim hoce da kaze. Lako je okrivti ga.....Balasevic je boem koga je, za mnoge, tesko razumeti. Ocigledno covek ne voli granice i ne bira strane..... mozda cak i treba ponesto od njega da i naucimo. Djole je za sve nase muzicare legenda....to stoji. Ko od nasih moze da uradi ono sto on radi? Da puni tribine gde god da peva....Da li je to Hrvatska, Slovenija, Srbija.....nije bitno"

а) Текст пред нама је интервју са Ђорђем Балашевићем поводом премијере његовог филма Као рани мраз. Текст интервјуа се може пратити и на основу карактеристика класичног интервјуа, као што су успешно вођење дијалога, конкретна питања која се на прави начин односе на тему, кратки одговори који довољно образлажу, и сл. Из тог угла посматран, ово је један веома успешан интервју који се у електронском издању ни мало не разликује од своје штампане верзије у Блицу.

б) На плану стилистике, изворни текст се одликује далеко већом прецизношћуизразаипрофесионалношћуформеодсамихкоментара. Богатство лексике и синтаксе као и прецизност граматике основног текста углавном се не може наћи у самим коментарима. Разумљиво, коментари се реализују уз учешће великог броја разноврсних аутора. Сваки такав текст представља особиту организацију и структуру, довољно продуктивну да у себи садржи одређени став аутора.

61) Основна одлика коментара $и$ јесте та разноврсност како стилске тако и тематске реализације. Уз то, иако је медијум комуникацијског остварења коментара писмена кореспонденција, они више наликују говорној комуникацији. Са тог становишта, стилски су неутралнија питања новинара, док се одговори Ђорђа Балашевића могу посматрати као стилски активан говор - маркиран нижим или вишим степеном експресивизације, и то како на лексичком, тако и на синтаксичком плану. 
б2) Најнижи степен стилизације показују они Балашевићеви искази у којима налазимо експресивизацију у виду колоквијализације језичке грађе:

- Hej? Podsećam vas da pričate s likom koji je napisao „Sve prave su ljubavi tužne...", a Vasina ljubav je prava, to smo se valjda dogovorili?

- pojavile su se lopine koje ne kradu više samo stihove i ideje iz pesama, nego su počeli da marišu i glavne junake...

- Iz prvopomenute serije video sam nekoliko kadrova, tek koliko mi se zaglavilo dugme na daljinskom...

Виши ниво стилизације показују случајеви Балашевићевог говора у којима се налазе трагови есејизације или поетизације израза:

- Vasa se odavno oteo i nastavio da živi nekim svojim životom, krišom je stizao tamo gde niko odavde jedno vreme nije smeo, tvrdoglavo ostajao u gradovima iz kojih su svi drugi pobegli. Dugo već nemam starateljstvo nad njim. Smatraju ga svojim gde god ga razumeju bez titla, nailazim na njegove tragove čak i na kontinentima na koje kročim prvi put, citiraju mi ga šapatom iz mraka, njegovim rečima kite narodnjačke refrene.

б3) Није то јест једнозначно лако одредити стилски тип текста у интернет новинарству. Како уопште одредити стил електронских тј. интернетских текстова - пита се и М. Катнић-Бакаршић (1999: 24). „Још је култни теоретичар масовних медија Лухан указао на 'медиј порука', што значи да природа медија битно одређује форму, али и садржај поруке. Јасно је и да стил поруке не може при том остати непромењен. Постструктурална стилистика овдје употребљава термин хипертекст да би означилатекстовехипермедија, нпр.интернетаислично, азбогспецифичне природе таквог текста он се не издваја у оквиру функционалних стилова, већ се о њему говори у оквиру стилистике текста".

64) Нешто друкчије Тошовић (2002: 390) разуме језичку ситуацију у незваничним препискама, приватној електронској пошти и у 
интернет причаоницама - објашњавајући је доминацијом писменог облика разговорног стила. Он наводи одређене особености овакве форме комуникације, које се лако распознају и у примеру одабраном за анализу, а то су: лаконичност, економичност и фамилијарност, те и штампарске, ортографске, граматичке и стилске грешке, али се као типична стилска особина електронске писмености несумњиво издваја модификација - оличена у различитим формама скраћивања.

в) Коментари ${ }^{13}$ се од самог текста на основу кога су настали, стилски много разликују, али оно што их нераскидиво повезује јесте тема на коју се односе, и могу се посматрати само у овој задатој дискурсној констелацији. Текст сам по себи јесте довољан да пружи информације о теми; међутим, права, потпуна слика свих догађаја који се односе на тему текста може се схватити само на основу додатног читања и самих коментара. Могућност остављања коментара на било који прочитани текст (што је једна од предности интернет издаваштва) у великој мери доприноси стварању јасног оквира око теме која се обрађује. Што више читалаца дође у додир са текстом, коментари ће бити разноврснији, али и сама тема и начин њене обраде условљава квалитет коментара. Интересантан и професионално написан текст ће привући већи број читалаца који могу својим мишљењем у виду коментара употпунити основни облик новинске вести.

в1) Са ортографског аспекта најупадљивије карактеристике интернет коментара тичу се графије и ортографије, чија је доминантна црта тенденциозно промењено писање са јасним циљем одступања од норматива. Ако почено од избора алфабета уочићемо да се изостављају дијакритички знаци - ̌̌: postujem, sta, slusali, sale; $\check{c}$ : cekala, cudite, razocarala; ć: hoce, Balasevic; ž: obozavam, kaze; đ: izmedju, Djole; - уочићемо, надаље, специфичан графички дизајн овог онлајн писма: уочавамо, то јест, потпуно нова правописна правила. Што се тиче знакова интерпункције, они у онлајн правопису имају сасвим нову функцију. Прво, изостављење или прекидање говора обележено је не конвенционалним трима тачкама, већ оказионално са пет та-

13 Од 232 коментара који прате ординарни текст, ми смо издвојили два да их детаљније промотримо. Резултати наше анализе могу се без већих одступања односити и на главнину коментара које смо из практичних и техничких разлога изоставили. 
чака: [.....], а екскламација уместо узвичником исказује се употребом четири узастопна узвичника [!!!!].

Екскламативни тон којим одише стил читавог текста може се сместити изван граница традиционалног новинарског стила. Узвик на самом почетку доприноси обилажењу професионализма и појачава утисак необавезног излагања. Облик вокатива колоквијално употребљен на самомпочетку коментара може се сматрати једним од главнихмаркера како тона у коме текст треба читати, тако и угла из кога би овај текст стилски требало посматрати. Наиме, то је узвик читалаца. Узвик у облику израза који представља реакцију људи због цене улазнице, израз који није дорађиван, на било који начин стилски обогаћиван нити цензурисан, то је израз који се просто отео из грла у првом тренутку сазнавања информације, и то је оно што на веома посебан начин обележава овај коментар уносећи у њега живост. Све ово иде у прилог природности обраде теме, као једној од основних карактеристика коментара.

Нестандардним комбиновањем интерпункцијских знакова - може се приметити - настају нови симболи, емотикони, помоћу којих комуникатори дочаравају своје стање или расположење у тренутку комбинације. Исп. у нашем првом коментару: :/// - у значењу изразитог незадовољства. Разлог употребе оваквог симбола формалне је природе - реч је о језичком економисању простором за комуникацију. Додуше, економише се и физичком активношћу куцања текста и временом, тј. брзином писања. Симболиком се, међутим, комуникација не само допуњује, већ се врло често вербални код супституише графијским скицама чинећи тзв. 'онлајн пиктографију'. И уопште, на свим граматичким нивоима (о чему ће надаље бити речи) јављају се алокуције, кондензација, брахилогија, пикнофразија, и најчешће - сажимања фразе. Овакав комуникацијски код окарактерисан је као 'рестринговани' 14 (ограничени), и употребљава се у опозицији према 'елаборираном' (развијеном) коду.

в2) На лексичкомплануупадљива јеупотреба интензификатора како би се нагласила експресивност исказа и како би се опис хиперболисао: Djole je za sve nase muzicare legenda....to stoji. Ko od nasih moze da uradi ono sto on radi? Da puni tribine gde god da peva. Ово

14 Исп. о томе више у Дурбаба (2010: 265). 
су истовремено примери жаргонизације и колоквијализације израза. Допринос жаргонској колоквијализацији доприноси и неофицијелна употреба властитих имена, тј. надимака: Djole, Mika, grbavica021. Нису изостали ни паравербални сигнали, тј. графостилеми: Мa mnoooooooooooooogo je. С тим у вези, на морфолошком плану налазимо одступање у писању 2. лица множине потенцијала: razumeli bi ste sta on ovim hoce da kaze, а неисправно је написан и радни глаголски приде: Lako je okrivti ga, што се може протумачити и као словна грешка.

в3) Синтаксички угао посматрања коментара примарно указује на симплификоване, често крње и недовршене реченичне структуре, неформалне, некохезионе и стихијске структуре у којима доминирају финитни глаголски облици: ......razumeli bi ste sta on ovim hoce da kaze, .....mozda cak i treba ponesto od njega da i naucimo, Djole je za sve nase muzicare legenda....to stoji. Da li je to Hrvatska, Slovenija, Srbija.....nije bitno. Сходно томе, можемо приметити у нашем примеру да сваки од аутора коментара има потребу за оптималном квантитском формом, али и оптималним узајамним разумевањем од стране других читалаца. Практична комуникацијска функција речи у овим текстовима не добија никакву надградњу, она заправо и остаје таква каква јесте, основна функција речи без вишег смисла. Тај виши смисао речи који се у овим текстовима углавном избегава само би допринео замагљивању основне нити која повезује све коментаре заједно са новинским текстом, око кога настају, у једну целину.

в4) И управо са тематског гледишта проматрани, у првом коментару који је овде приказан можемо пронаћи једну од основних њихових карактеристика. Наиме, са сигурношћу се може констатовати да коментаре о одређеним темама постављају читаоци који се углавном разумеју у постављене теме. Тако у овом примеру у основном тексту интервјуа ни на једном месту није поменута цена улазнице, а основна тема овог коментара управо је то, што значи да је аутор овог текста унапред био упознат са ситуацијом, па га тако та констатација ставља у ред познавалаца теме коју коментарише.

в5) Други коментар који је овде представљен може се посматрати као нова микроцелина у макроцелини текста читавог интервјуа. У овом 
коментару на идеалан начин се може сагледати слободна употреба интерпункције, као још једна од карактеристика коментара. Наиме, читав текст овог коментара просто је маркиран паузама. Паузе које се веома слободно распоређују кроз читаву структуру текста - скоро у свим случајевима представљају места на којима и нема граматичког разлога паузама, али аутор као да је желео да се управо на тим дискурсним пунктовима посебно задржи, на нарочити начин истичући значај постпонираних речи. Та антиципирана места јесу констатације које се тичу како самог текста интервјуа, тако и претходних коментара. Из овог примера се може закључити да се употреба интерпункције у коментарима читалаца веома разликује од њене традиционалне, правописом утврђене употребе у самим новинским текстовима - у кометнарима сфера њене употребе се у великој мери проширује, наиме постаје и практична, тачније: прагматична.

Тематски посматрано, други коментар се може сматрати одговором првом коментару, тако да у целини узевши ова два кометара чине две стране исте приче, две супростављене стране употпуњавајуће комуникативне вредности. Узети и као целина, а и у односу на текст интервјуа - може се устврдити да коментари имају комплементарну функцију.

4. И коначно, након читања коментара уз основни текст интервјуа може се стећи потпуна слика о теми коју обрађује новински текст. Негативни коментар супростављен позитивном на прави начин доприноси заједничком осликавању шароликости читалачке публике и различитих начина на које иста информација бива схваћена код различитих профилачиталаца, а такође, и веома јасно слика слободније границе у којима се налази писање коментара у односу на оквире новинских текстова. Та разноврсност различитих стилова, форми, тема која се може пронаћи само у коментарима - у великој мери доприноси квалитету штампе која је доступна за читање путем интернета.

\section{3. Закључне напомене}

1. Интернет новинарство настало је у тренутку кад је људско друштво достигло тачку толике развијености у којој је себи 
обезбедило све кључне погодности за даљи развој и од које је кренуло да те погодности још више усавршава. Интернет као медиј у себи садржи комбинацију писаних медија и телевизије, тако да и интернет издаваштво подразумева комбиновање писаних и аудио и видео записа. 3бог тога се новинарство на интернету може сматрати далеко комплекснијом појавом него што је то случај са новинарством које прате штампани медији.

2. Такође, сам начин организовања текста у онлајн часописима и новинама далеко се разликује од текста штампаних издања. Наиме, основна карактеристика текстова који се могу читати у онлајн штампи јесте нелинеарно писање у више равни, означено као хипертекст. Такав текст почива на сложеној структури која подразумева густу мрежу линкова који се појављују у виду асоцијативних веза када се у тексту за то укаже прилика. Ти линкови представљају смернице на основу којих се може кретати из текста у текст, и на тај начин долази до преплитања више различитих текстова у којима је читалац у улози аутора јер сам конституише текст који ће прочитати.

3. Анализа примера интернетновинарства дозвољава закључити да овај принцип организовања текста на интернету није спроведен у текстовима онлајн издања новина и часописа у нашој земљи, што показује велику неискоришћеност могућности које пружа интернет. Са друге стране, посматрајући насловне стране електронских издања може се устврдити да су оне организоване на принципу које прописује интернет издаваштво, што се може сматрати великом предношћу у односу на штампана издања.

4. У области стилистике - интернет новинарство у основи пружа све основне карактеристике које одликују добар новинарски текст (исп.: Јовановић 2010). Посебно истицање садржаја испред форме, а уз то бити први и тачан у информисању јесте добитна комбинација која гарантује успех. Но ипак ваља додати да брзина настајања интернет текстова, слобода израза, и лежерност која са овим иде, омогућују сваком писменом или полуписменом човеку да се укључи у' дискусијуे, уносећи у текст све особености свакодневног говора, као и писања без довољног увида у норму. Тиме је омогућен продор и недовршених и недомишљених изјава, неодмерених речи и израза, некомпетентних 
оцена итд. Свим овим и много чиме још - интернет може повући новинарство, и уопште јавну реч, јаком струјом према неуљудном говору, према неодговорној мисли, према неписменом исказу итд.

5. У крајњој инстанци, предности интернет новинарства су многе, а пре свега су садржане у чињеници да се сваког тренутка појављују нове опције, нове могућности које од овакве врсте новинарства чине чврст основ напретка који ће једног дана, сигурно, довести до тога да штампано издаваштво, и новинарство које је ограничено само на штампане медије, буде потиснуто, а можда и потпуно заборављено. Али исто тако много и опасности по друштво, по опште стање и духовну атмосферу друштва - носи ова новина у комуникацијском процесу. 3бог тога се Давид Нордфорс (2010), аутор текста Раздвајање новинарства и медија, с правом пита: „Шта ће се десити са новинарством?“.

\section{ИЗВОР}

http://www.blic.rs/Zabava/Vesti/184763/Ovo-je-lepa-prica-o-Vasi-Ladackom/ komentari\#ostali, 14. април 2010.

\section{ЛИТЕРАТУРА}

Вујаклија М. 1991: Лексикон страних речи и израза, 4. издање, Београд: Просвета. Гиденс 1998: E. Gidens, Posledice modernosti, Beograd: Filip Višnjić.

Дурбаба 2010: О. Дурбаба, Особености рестрингованог кода друштвене мреже фејсбук (Facebook) на интернету: „Еvo me faceboochim“, Научни састанак слависта у вукове дане, 39/1, 265-277.

Ивановић 2006: С. Ивановић, Виртуелна култура и социјалне комуникације младих, у: Лакета Н. (ур). Зборник радова - Ужице: Универзитет у Крагујевцу. Учитељски факултет Ужице. Учитељски факултет Ужице.

ИМК 1980: Много гласова један свет! У: Извештај Међународне комисије за изучавање проблема комуникације, Београд: Танјуг у сарадњи са Југословенском комисијом UNESCO.

Јовановић 2010: Ј. Јовановић, Лингвистика и стилистика новинског умећа, Београд: Јасен.

Катнић-Бакаршић 1999: M. Katnić-Bakaršić, Lingvistička stilistika, Budapest: E-Publishing. 
Клајн и Шипка 2008: И. Клајн и М. Шипка, Велики речник страних речи и израза, Нови Сад: Прометеј.

Коадик 2005: Ив-Франсоа Ле Коадик, Наука о информацијама, Београд: Клио.

Кристал 2001: D. Crystal, Language and Internet, Cambridge: CUP.

Миловановић 2003: G. Milovanović, Internet i globalizacija: zavojite staze ka informatičkom društvu, Zb. Aspekti globalizacije, Beograd: Beogradska otvorena škola.

Младенов 1980: М. Младенов: Новинарска стилистика, Београд, Научна књига.

Новосел и др. 2006: С. Новосел и др., Интернет-новинарство. Приручник за радионицу. Крижевци: П.О.И.Н.Т.

Нордфорс 2010: Д. Норфорс, Раздвајање новинарства и медија. [Интернет]. Доступно на: http://www.media.ba/mcsonline/bs/tekst/razdvajanje-novinarstva-i-medija.

Собел 1981: M. E. Sobel, Lifestyle an Social Structure, New York: Academic Press.

Станојевић 2010: 3. Станојевић, Места за све колумнисте. [Интернет]. Доступно на: http://www.blogodak.com/?search=naravno\&page=380 , 21. mart, 2010.

Стојковић 2002: Б. Стојковић, Границе на Балкану и виртуелни простор Интернета, У: Културни ии етнички идентитети у процесу глобализације и регионализације Балкана, Београд: ЦБС и ЈУНИР.

Тадић 2002: Св. Тадић, Снага и немоћ јавне речи, Београд: Завод за уџбенике и наставна средства.

Тошовић 2002: Б. Тошовић, Функционални стилови, Београд: Београдска књига.

\author{
Jelena R. Jovanovic Simic \\ University of Belgrade \\ Faculty of Philology
}

\title{
ON CERTAIN CHARACTERISTICS OF SERBIAN INTERNET JOURNALISM
}

\begin{abstract}
Summary
The author starts from the observation that the internet news have become, almost imperceptibly, ubiquitous. One of the main common characteristics of all internet newspapers is mostly reflected in the advantages on which the internet publishing rests upon. (a) The availability of information is a major advantage that characterizes internet journalism in comparison to the traditional form of journalism. Everyone can find what interests them the most through very quick and easy search. (b) Despite the fact that the internet editions have the same columns as the printed ones, they are characterized
\end{abstract}


by the existence of new, additional columns that can be best and solely presented on the Internet (video and audio recordings, etc.). (c) The very articles in online editions offer great opportunities primarily due to the form of hypertext - these texts are actually much longer than articles in printed publications. (d) Finally, publishers and authors of the texts are more daring, allowing themselves more freedom in writing, considering that the internet editions are less censored. This certainly provides more opportunities starting from collecting information through their formulation up to the publication of the very text. (e) In addition to the above, it should be noted that each online edition has a special place foreseen for the letters and comments of readers, which leads to better communication between readers and editors.

Key words: internet news, internet journalism, internet publishing, internet edition, hypertext 